\section{Nyttig om langtidsoverlevende
kreftpasienter}

Fosså SD, Loge JH, Dahl AA, red. Kreftoverlevere

Ny kunnskap og nye muligheter i et langtidsperspektiv. $247 \mathrm{~s}$, tab, ill. Oslo: Gyldendal Akademisk, 2009. Pris NOK 325 ISBN 978-82-05-39204-5

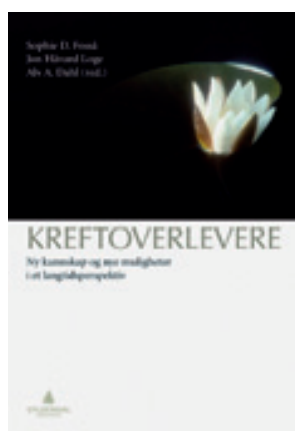

Å få en kreftdiagnose er for de fleste en traumatisk opplevelse, og mange, også medisinsk kyndige, vil umiddelbart se for seg det verst tenkelige utfall. I dag blir imidlertid nærmere $60 \%$ kurert for kreftsykdommen. Dette

tilsier at mange lever etter gjennomgått behandling. Moderne kreftbehandling er mangeartet, og mange vil gjennomgå både kirurgi, kjemoterapi og strålebehandling. Vår kunnskap om langtidsbivirkningene har vært begrenset, men i de senere år er oppfølging og etterkontroller satt i system. I Norge har vi et fortrinn når det gjelder forskning på kreftoverlevere grunnet Kreftregisterets systematiske datainnsamling gjennom mer enn 50 år og våre muligheter til å følge disse pasientene $\mathrm{i}$ behandlings- og oppfølgingstiden i mange år. Kreftoverlevere er den første utgivelse på norsk som systematiserer vår viten om seneffekter etter kreftbehandling, og forfatterne skal ha honnør for å ha samlet ny kunnskap i en lærebok.

Hva er definisjonen på en kreftoverlever - ett års overlevelse, fem års overlevelse eller at man faktisk er biologisk kurert for kreften? Begrepet forstås noe ulikt, men her omhandles hele tidsperioden etter at primærbehandlingen er avsluttet. Dette gjør at boken spenner vidt, fra beskrivelse av primær kreftbehandling til langtidseffekter etter stråling, med oppfølgingstid på mange år. Vi vet at langtidseffektene av stråling kan være store, hvilket gjør at man legger stor vekt på at primærbehandlingen skreddersys med det for øye å minimalisere den innledende kreftbehandlingen, hvis man kan. Behandlingen av f.eks. testikkelkreft og lymfekreft er strukturerte protokoller og behandlingsopplegg som tester ut redusert intensiv kjemoterapi og strålebehandling, gitt ut fra prediktive faktorer.

Mange kreftpasienter opplever betydelig utmattelse (fatigue) etter gjennomført behandling. Disse symptomene er ikke lett å forklare, og som regel er det få eller ingen objektive funn. Forfatterne diskuterer dette fenomenet grundig, men vi mangler fortsatt kunnskap om metoder for forebygging og håndtering $\mathrm{av}$ disse senplagene.

Kreftoverlevere er forst fremst rettet mot helsearbeidere, men pasienter og pårørende er også en målgruppe. Tre kapitler som omhandler fysisk aktivitet, ernæring og trygdeytelser er godt skrevet og vil være nyttig lesning for disse. Alt $\mathrm{i}$ alt må man si at denne utgivelsen dekker et behov.

\section{Stein Sundstrøm}

Klinikk for kreft og hudsykdommer

St. Olavs hospital

\section{Svakt om tinnitus}

Thomassen S.

\section{Selvhjelp ved tinnitus}

Hvordan mestre plagsom øresus. $148 \mathrm{~s}$ Oslo: Tinnitus-Tips, 2009. Pris NOK 195 ISBN 978-82-929-3703-7

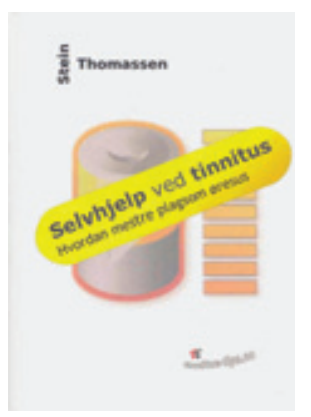

Forfatteren har på eget forlag utgitt en veiledning i selvhjelp for personer med øresus. Bakgrunnen er at han selv har nedsatt hørsel og øresus. Han er elektroingeniør og har de senere år drevet med informasjon og kursvirksomhet om problemet.

Selvhjelpen bygger på en nevrofysiologisk forståelse av tilstanden. Thomassen formidler Jastreboffs metode for omlæringsbehandling, som har som mål at øresusen skal oppfattes som betydningsløs og ufarlig. Videre inngår kognitiv atferdsterapi, med avspenning, remodellering av tanker og bruk av utfordrende situasjoner, for å bedre den plagedes holdninger til problemet. Forfatteren formidler en optimistisk holdning til at noe kan gjøres for å redusere ubehaget ved hjelp av de anviste metodene, men han legger stor vekt på at et godt resultat er avhengig av meget stor egeninnsats, grundig opplysning og tålmodighet. Han tar avstand fra skrekkhistorier og angstskapende informasjon.

Selvhjelp ved tinnitus er skrevet i en kåserende stil, og det er mye gjentakelser, slang og feil. Informasjonen og veiledningen er formidlet på en uoversiktlig måte - det er svært mange henvisninger til andre steder i boken, noe som vil vanskeliggjøre tilegning av stoffet. Forfatterens mangel på medisinsk bakgrunn kommer til syne når han skal gjøre rede for den medisinske forståelsen av øresus - bebreidelser mot helsepersonell om manglende kunnskaper om tilstanden kunne derfor med fordel vært utelatt. Stikkordregisteret på 15 sider er ubrukbart fordi sidehenvisningene ikke stemmer med pagineringen.

Personer med plagsom øresus finner bra veiledning til selvhjelp i denne utgivelsen, men bruksverdien ville blitt større etter en relativt omfattende revisjon.

Hans H. Elverland

$\emptyset$ re-nese-halsseksjonen

Nordlandssykehuset Lofoten

\section{Nyttig om akuttmedisinsk kommunikasjon}

Juvkam PC, Aksnes AO, Dreyer K et al.

Håndbok: Kommunikasjon og samhandling i akutte situasjoner

4. utg. 352 s, tab, ill. Bergen: KoKom, 2009

Pris NOK 150

ISBN 978-82-8210-010-6

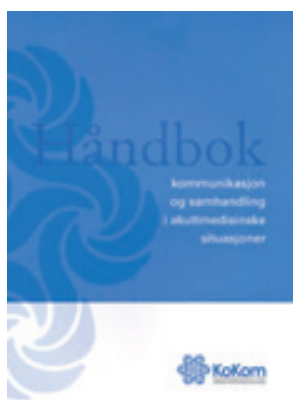

«KoKom» lyder den enkle forkortelsen for det mer krevende Nasjonalt kompetansesenter for helsetjenestens kommunikasjonsberedskap. Kompetansesenteret har som hovedoppgave å monitorere og

videreutvikle den medisinske nødmeldetjenesten i Norge. Dette er en viktig oppgave, men aller viktigst er det jo at alle aktørene i den akuttmedisinske kjeden kjenner sys- 